\title{
Vulnerability of Nucleic Acids in Mutant Staphylococci with Impaired Respiration
}

\author{
By G. F. GAUSE AND G. V. KOCHETKOVA \\ Institute of Antibiotics, Academy of Medical Sciences, Moscow, U.S.S.R.
}

(Received 23 January 1962)

\begin{abstract}
SUMMARY
Mutant staphylococci with impaired respiration, induced by ultraviolet radiation, were used for testing various inhibitors with already known mechanisms of action. Inhibitors of protein synthesis (the tetracyclins) affected the growth of parent and mutant cultures to the same degree. To the inhibitors of cell-wall synthesis (the penicillins) mutant staphylococci were more resistant than the parents; this was related to the altered amino acid composition of cell-wall material in the mutants. On the other hand, the mutants were much more vulnerable than parents to the action of inhibitors which affected the nucleic acids - namely, mitomycin $\mathbf{C}$ $(\times 50$ times), actinomycin $\mathrm{C}(\times 50)$, trypaflavine $(\times 300)$, nitrogen mustards ( $\times 10-20)$. A specific thymine synthetase inhibitor (5-fluorodeoxyuridine) strongly inhibited the growth of parent staphylococci, but did not at all inhibit the growth of mutants. This points to some deficiency in the enzymic mechanism of synthesis of thymine in the DNA of mutants. Experiments with 5-bromodeoxyuridine suggest that the mutant staphylococci lacked the enzymic mechanism necessary for effective incorporation of halogenated pyrimidines into the DNA precursor pool.
\end{abstract}

\section{INTRODUCTION}

Mutant yeast cells with impaired respiration, enhanced glycolysis, a distorted cytochrome system, and which formed 'small colonies' (Ephrussi, Hottinguer \& Chimenes, 1949), have attracted the attention of numerous investigators (e.g. Lindegren, 1959). The search for mutants with impaired respiration in other microorganisms has led to detection of characteristic mutant staphylococci, with 'small colonies', respiration deficiency, and altered cytochromes (Gause, Kochetkova \& Vladimirova, 1957; Gause, 1960). Mutant staphylococci with impaired respiration are selectively inhibited by substances that primarily affect the synthesis of cell nucleic acids. Some new observations along these lines are described here.

\section{METHODS}

Organisms. Staphylococcus aureus strain 209 (National Collection of Industrial Bacteria, NCIB, 9308) was used. Mutants with impaired respiration uv-2 (NCIB 9309) and uv-3 (NCIB 9310) were induced in this strain by ultraviolet (u.v.) irradiation, as described previously (Gause et al. 1957).

Medium. The organisms were grown in nutrient broth, containing (per litre of medium) tryptic digest of meat, $30 \mathrm{ml}$; peptone, $5 \mathrm{~g}$.; sodium chloride, $5 \mathrm{~g}$.; glucose, $10 \mathrm{~g}$. Tryptic digest of meat was a commercially available Hottinguer boullion; for its preparation meat was digested by Pancreatinum Siccum $48 \mathrm{hr}$. at $37^{\circ}$, filtered, and adjusted to a concentration of $700 \mathrm{mg} \% \mathrm{NH}_{2}-\mathrm{N}$. 
Estimation of bacteriostatic concentrations. Bacteriostatic action of various inhibitors was estimated in test tubes containing $2 \mathrm{ml}$. of nutritive broth, at $37^{\circ}$, by serial dilution method. For inoculation, cultures of bacteria were grown overnight in nutritive broth at $37^{\circ}$, adjusted turbidimetrically to a population density of $5 \times 10^{8} / \mathrm{ml}$., and added to each tube in the amount of $0.05 \mathrm{ml}$. After $18 \mathrm{hr}$. of incubation at $37^{\circ}$ the maximal dilutions of preparations were recorded in which the growth of bacteria was absent and the liquid remained transparent. Each experiment was repeated ten times, and the average data are presented in the Tables.

Ultraviolet irradiation. Organisms were treated with u.v. radiation at $2540 \AA$, with a radiation intensity of $11.53 \mathrm{erg} / \mathrm{sec}$. transmitted to each $\mathrm{mm} .{ }^{2}$.

\section{RESULTS \\ Effects of inhibitors of protein synthesis}

Gale \& Folkes (1953) observed that chlortetracycline and oxytetracycline stopped the growth of staphylococci in nutrient broth by selective inhibition of protein synthesis; nucleic acid synthesis, however, continued in the presence of bacteriostatic concentrations of these antibiotics. Our results showed that tetracycline and chlortetracycline inhibited the growth of the parent and mutant staphylococci to the same degree (Table 1).

Table 1. Bacteriostatic action of various inhibitors upon the growth of parent and mutant cultures of Staphylococcus aureus
(1) Inhibitors of protein synthesis Tetracycline Chlortetracycline
(2) Inhibitors of cell-wall synthesis Penicillin G Phenoxymethylpenicillin

(3) Inhibitors of nucleic acid synthesis Mitomycin $\mathrm{C}$ Actinomycin $\mathbf{C}$ Trypaflavine N-mustards (Degranol)

(4) Other inhibitors Chloramphenicol

\begin{tabular}{|c|c|}
\hline Parents & Mutants (uv-2, uv-3) \\
\hline $\begin{array}{l}0.09-0 \cdot 10 \mu \mathrm{g} . / \mathrm{ml} .^{*} \\
0 \cdot 15-0 \cdot 18 \mu \mathrm{g} . / \mathrm{ml} .\end{array}$ & $\begin{array}{l}0.09-0.15 \mu \mathrm{g} . / \mathrm{ml} \text {. } \\
0.20 \mu \mathrm{g} . / \mathrm{ml} .\end{array}$ \\
\hline $\begin{array}{l}0.008 \text { units } / \mathrm{ml} \text {. } \\
0.007 \text { units } / \mathrm{ml} \text {. }\end{array}$ & $\begin{array}{l}0.06-0.07 \text { units } / \mathrm{ml} \text {. } \\
0.06 \text { units } / \mathrm{ml} \text {. }\end{array}$ \\
\hline $\begin{array}{l}0.0750 \mu \mathrm{g} . / \mathrm{ml} . \\
0.250 \mu \mathrm{g} . / \mathrm{ml} . \\
3 \mu \mathrm{g} . / \mathrm{ml} . \\
2 \mathrm{mg} . / \mathrm{ml} .\end{array}$ & $\begin{array}{l}0.0015 \mu \mathrm{g} . / \mathrm{ml} \\
0.005 \mu \mathrm{g} . / \mathrm{ml} \\
0.01 \mu \mathrm{g} . / \mathrm{ml} \\
0.2 \mathrm{mg} . / \mathrm{ml}\end{array}$ \\
\hline $6-8 \mu \mathrm{g} . / \mathrm{ml}$ & 2-3 $\mu \mathrm{g} . / \mathrm{ml}$ \\
\hline
\end{tabular}

\section{Effects of inhibitors of cell-wall synthesis}

Bacteriostatic concentrations of penicillin which selectively inhibit biosynthesis of cell wall do not disturb the synthesis of proteins and nucleic acids in staphylococci (Strominger, Park \& Thompson, 1959; Rogers \& Perkins, 1959). It is clear from Table 1 that the mutant staphylococci, as compared with the parents, were about eight times more resistant to the inhibitory action of the penicillins in nutrient broth. It may therefore be suggested that mutants differ from the parent organism in the biosynthesis of the cell-wall material, which is selectively affected by penicillin. Cell-wall material in the mutants appeared to be more resistant to the disruptive action of penicillin. This is in accord with chemical studies which have 
shown that the amino acid composition of the cell-wall material in parent staphylococci is different from that of their mutants (Gause, Kochetkova \& Vladimirova, 1961).

\section{Effects of inhibitors of nucleic acid formation}

Mitomycin C. Shiba, Terawaki, Taguchi \& Kawamata (1959) observed that mitomycin $\mathrm{C}$ in dilute solution selectively inhibited the formation of deoxyribonucleic acid (DNA) in bacteria, while synthesis of protein and ribonucleic acid (RNA) remained unaffected. Our results showed that mutant staphylococci were fifty times more vulnerable than the parent culture to the action of mitomycin $\mathbf{C}$.

Actinomycin C. Reich, Franklin, Shatkin \& Tatum (1961) reported the selective action of actinomycin $\mathrm{C}$ on RNA synthesis in bacteria. We observed that the mutants were fifty times more vulnerable than parents to the inhibitory action of actinomycin $\mathrm{C}$.

Trypaflavine. Trypaflavine (3:6-diamino-10-methylacridine chloride) is a mitotic poison which selectively inhibits DNA synthesis (Morthland, De Bruyn \& Smith, 1954). We observed that with this compound the mutants were 300 times more vulnerable than the parents.

Table 2. Concentrations of 5-fluorouracil required to cause inhibition of growth of parent staphylococci and of their mutants, in the presence of various concentrations of uracil*

$\begin{array}{ccc}\text { Micro-organism } & \begin{array}{c}\text { Uracil } \\ (\mu \mathrm{g} . / \mathrm{ml} .)\end{array} & \begin{array}{c}5 \text {-Fluorouracil } \\ (\mu \mathrm{g} . / \mathrm{ml} .)\end{array} \\ \text { Parent staphylococci } & 0 & 125 \\ & 10 & 200 \\ & 100 & 500 \\ \text { Mutant strain uv-3 } & 1000 & \mathbf{7 5 0} \\ & 0 & 2 \\ & 10 & 6 \\ & 100 & \mathbf{2 5} \\ & 1000 & \mathbf{7 5}\end{array}$

* See footnote to Table 1 .

Nitrogen mustards. The nitrogen mustards as a group are potent inhibitors of DNA synthesis. By carefully grading the doses, a value can be chosen where synthesis of DNA is blocked completely, while synthesis of protein and RNA continue (Shepherd, 1958). Degranol [1,6-bis-( $\beta$-chloroethylamino)-1,6-deoxy-Dmannitol, manufactured by Chinoin Ltd, Budapest] was used as a representative of this group of compounds; it is a combination of nitrogen mustard with mannitol and is soluble in water. The mutants were ten times more vulnerable than the parents to the action of degranol. The selective inhibition of growth of mutant staphylococci has been recorded for other nitrogen mustards (Gause, 1960). Triethylene melamine, which specifically affects pyrimidines in the synthesis of bacterial DNA (Szybalski, 1960a), also selectively inhibits the growth of mutant staphylococci (Gause et al. 1961).

Halogenated pyrimidines. This group of compounds is of particular interest for the study of the vulnerability of nucleic acids in mutant staphylococci with impaired respiration. It is known that 5-fluorouracil acts as a specific inhibitor of RNA 
synthesis; it can be incorporated into bacterial RNA, where it may replace, in part, the uracil normally present. The synthesis of DNA, however, is not affected (Horowitz \& Chargaff, 1959). We observed that 5-fluorouracil at $125 \mu \mathrm{g} . / \mathrm{ml}$. inhibited the growth of the parent staphylococcus in broth. Addition of thymine (100 $\mu \mathrm{g} . / \mathrm{ml}$.) to the nutrient medium produced no effect, but addition of uracil annulled the inhibitory action of 5-fluorouracil. The annulment of the inhibitory action of 5 -fluorouracil in the presence of uracil was competitive; see data presented in Table 2.

For the mutant staphylococci (uv-2, uv-3) the inhibitory concentration of 5fluorouracil was $2 \mu \mathrm{g}$. $/ \mathrm{ml}$.; this inhibitory action was not affected by thymine (100 $\mu \mathrm{g} . / \mathrm{ml}$.), but with uracil it was competitively annulled (Table 2). It may be concluded that in the parent and mutant staphylococci 5 -fluorouracil specifically inhibited RNA synthesis, but did not affect DNA synthesis. It appears therefore that the synthesis of RNA in mutants was about sixty times more vulnerable to the action of 5 -fluorouracil than it was in the parents.

It is of interest that 5-fluorodeoxyuridine (FUDR), in experiments with various bacteria, specifically inhibited synthesis of DNA (Cohen et al. 1958). We observed that FUDR at $25 \mu \mathrm{g} . / \mathrm{ml}$. inhibited the growth of the staphylococcus in broth. Addition of uracil (100 $\mu \mathrm{g} . / \mathrm{ml}$.) produced no effect, but addition of thymine competitively annulled the inhibitory action of FUDR on the parent staphylococcus (Table 3). By inhibiting the synthesis of thymine, FUDR apparently interfered with the formation of DNA in the parent staphylococci. It is remarkable, therefore, that FUDR did not inhibit the growth of the mutant staphylococci with impaired respiration (uv-2, uv-3, and all other available mutants of this type), up to the maximal concentration tested $(1000 \mu \mathrm{g} . / \mathrm{ml}$.). If FUDR is a specific thymine synthetase inhibitor, the absence of inhibitory action on the mutant staphylococci points to some deficiency in the enzymic mechanism of synthesis of thymine in these mutants.

Table 3. Concentrations of FUDR required to cause inhibition of growth of parent staphylococci in the presence of various concentrations of thymine*

$\begin{array}{cc}\text { Thymine } & \text { FUDR } \\ (\mu \mathrm{g} . / \mathrm{ml} .) & (\mu \mathrm{g} . / \mathrm{ml} .) \\ 0 & 25 \\ 10 & 60 \\ 100 & 100 \\ 1000 & 200 \\ \text { * See footnote to Table } 1 .\end{array}$

We also observed that certain brominated pyrimidines (e.g. 5-bromouracil, 5bromodeoxyuridine, BUDR), did not inhibit the growth of either parent or mutant staphylococci in nutrient broth, up to the maximal concentration tested (500 $\mu \mathrm{g}$. ml.). Lorkiewicz \& Szybalski (1960) observed that in the presence of FUDR thymine synthetase was inhibited and a state of thymine deficiency was produced in the cells, and the incorporation of BUDR, the thymidine analogue, into the bacterial DNA can be observed. The substitution of thymidine in the DNA by its brominated analogue (BUDR) renders the cells highly sensitive to the killing action of u.v. radiation (Szybalski, 1960b). 
We were able to reproduce this phenomenon with the parent staphylococcus used here. The cocci were grown for $18 \mathrm{hr}$. in nutrient broth containing FUDR (10 $\mu \mathrm{g} . / \mathrm{ml}$.), BUDR (10 $\mu \mathrm{g} . / \mathrm{ml}$.) or a mixture of FUDR + BUDR. Separately, as well as in admixture, these substances did not inhibit the growth of the staphylococci in the concentrations tested. Then the suspensions of staphylococci were adjusted turbidimetrically to a population density of $10^{8} / \mathrm{ml}$. of organisms, $0.05 \mathrm{ml}$. of dilution poured on to the surface of nutrient agar plates, and the plates u.v. irradiated for different times. The results obtained are shown in Table 4.

It is clear that with the parent staphylococcus grown in the presence of FUDR + BUDR the sensitivity to u.v. radiation was markedly increased. According to Szybalski $(1960 b)$ this sensitization directly follows the incorporation of BUDR into the bacterial DNA as a result of substitution of the halogenated analogue in place of thymidine. It is remarkable, therefore, that this phenomenon was not observed in the mutant staphylococci.

\section{Table 4. Ultraviolet light sensitivity of parent and mutant staphylococci grozon in the presence of FUDR, BUDR, or both}

\begin{tabular}{lrcrr} 
& \multicolumn{3}{c}{ Mean number of colonies per plate* } \\
\cline { 2 - 5 } $\begin{array}{l}\text { Irradiation } \\
\text { time }\end{array}$ & Control & FUDR & BUDR & $\begin{array}{r}\text { FUDR+ } \\
\text { BUDR }\end{array}$ \\
& & Parent culture & \\
15 sec & $\mathbf{5 0 0 0}$ & 4100 & $>5000$ & 540 \\
30 & 4400 & 1500 & 3000 & 14 \\
45 & 1700 & 340 & 1200 & 2 \\
60 & 220 & 20 & 30 & 0 \\
& & Mutants (uv-3) & & \\
1 min & $>5000$ & $>5000$ & $>5000$ & $>5000$ \\
2 & 660 & 650 & 600 & 550 \\
3 & 80 & 55 & 80 & 75 \\
4 & 35 & 35 & 25 & 37 \\
5 & 17 & 12 & 20 & 16 \\
& $*$ Counted after 72 hr. at $\mathbf{3 7}{ }^{\circ}$. &
\end{tabular}

The data presented in Table 4 show that the mutants were more resistant than the parent to the killing action of u.v. radiation. The interesting point, however, is that in mutants grown in the presence of FUDR + BUDR no sensitization was observed. This suggests that in the mutants the incorporation of halogenated thymidine analogues into DNA did not take place. It can be supposed that the mutant staphylococci lacked the enzymic mechanism necessary for effective incorporation of halogenated pyrimidines into the DNA precursor pool.

\section{Effects of other inhibitors}

Chloramphenicol. Chloramphenicol is an inhibitor of protein synthesis; more recent study has shown that this compound interferes with the synthesis of both protein and nucleic acids. It is possible that chloramphenicol blocks some stage in the mechanism of nucleoprotein synthesis, and that the sensitive stage lies somewhere between the activation of amino acids, their fixation by small 'nucleic acid' 
components, and the polymerization of these components into macromolecular structures (Gale, 1958). We observed that the mutants were about two to three times more sensitive than the parent to this compound (Table 1). These figures are similar to those for the tetracyclines, which inhibited the growth of the parent staphylococcus and of the mutants to the same degree. It might be supposed that the mechanism of the inhibitory action of chloramphenicol is similar to but not identical with that of the tetracyclines.

Table 5. Sensitivity to heat of normal staphylococei and mutants with impaired respiration

\begin{tabular}{ccc}
$\begin{array}{c}\text { Heating time } \\
\text { (min.) }\end{array}$ & $\begin{array}{c}\text { Normal } \\
\text { staphylococci }\end{array}$ & Mutant uv-3 \\
5 & $>5000$ & $>5000$ \\
10 & $>5000$ & 3500 \\
15 & $>5000$ & 1600 \\
20 & $>5000$ & 35 \\
30 & 3600 & 30 \\
60 & 400 & - \\
90 & 150 & - \\
120 & 69 & \\
\multicolumn{3}{c}{ * Counted after $72 \mathrm{hr}$. at $37^{\circ}}$.
\end{tabular}

Effect of heating. Suspensions of staphylococci $\left(10^{8} / \mathrm{ml}\right.$. of organisms) were heated in a water bath at $55^{\circ}$ for different periods of time, and then poured on to nutrient agar $(0.05 \mathrm{ml}$./ plate). Table 5 shows that the mutant staphylococci were much more sensitive to heat than was the parent. It is difficult to ascribe a reason for this phenomenon, but it is interesting to note that defects in nucleic acids make bacteria more sensitive to the lethal effect of elevated temperatures (Lorkiewicz \& Szybalski, 1960).

\section{REFERENCES}

Cohen, S., Flaks, I., Barner, H., Loeb, M. \& Lichtenstein, I. (1958). The mode of action of 5-fluorouracil and its derivatives. Proc. nat. Acad. Sci., Wash. 44, 1004.

Ephrussi, B., Hottinguer, H. \& Chrmenes, A. (1949). La mutation 'petite colonie'. Ann. Inst. Pasteur, 76, 351.

GALE, E. F. (1958). The mode of action of chloramphenicol. In the Ciba Foundation Symposium: Amino Acids and Peptides with Antimetabolic Activity, p. 19. London: Churchill.

Gale, E. F. \& Folkes, J. P. (1953). Actions of antibiotics on nucleic acid and protein synthesis in Staphylococcus aureus. Biochem. J. 53, 493.

GaUse, G. F. (1960). The Search for Nere Antibiotics. New Haven: Yale University Press.

Gause, G. F., Kochetkova, G. V. \& Vladimrrova, G. B. (1957). Biochemical mutants of staphylococci with impaired respiration. Dokl. Acad. Sci. USSR, 117, 720.

Gause, G. F., Kochetrova, G. V. \& Vladimirova, G. B. (1961). Biochemical changes accompanying impaired respiration in staphylococci. Dokl. Acad. Sci. USSR, 139, 223.

HoRowitz, J. \& ChargafF, E. (1959). Massive incorporation of 5 -fluorouracil into a bacterial ribonucleic acid. Nature, Lond. 184, 1213.

LiNDEGREN, C. (1959). Cancer and the respiratory grana. Nature, Lond. 184, 397. 
LoRkiewicz, Z. \& SzYBaLski, W. (1960). Genetic effects of halogenated thymidine analogs incorporated during thymidylate synthetase inhibition. Biochem. biophys. Res. Comm. 2,413 .

Morthland, F. W., De Bruyn, P. P. \& Smith N. H. (1954). Spectrophotometric studies on the interaction of nucleic acids with aminoacridines. Exp. Cell Res. 7, 201.

Reich, E., Franklin, R., Shatkin, A. \& Tatum, E. L. (1961). Effect of actinomycin D on cellular nucleic acid synthesis and virus production. Science, 134, 556 .

Rogers, H. I. \& Perkins, H. R. (1959). Cell-wall mucopeptides of Staphylococcus aureus. Nature, Lond. 184, 520 .

ShEPHERD, C. I. (1958). Inhibitors of protein and nucleic acid synthesis in Aspergillus nidulans. J. gen. Microbiol. 18, iv.

Shiba, S., Terawaki, A., Taguchi, T. \& Kawamata, I. (1959). Selective inhibition of formation of deoxyribonucleic acid in $E$. coli by mitomycin C. Nature, Lond. 183, 1056.

Strominger, J. L., Park, J. T. \& Thompson, R. E. (1959). Composition of the cell wall of Staphylococcus aureus: its relation to the mechanism of action of penicillin. J. biol. Chem. 234, 3263.

Szybalski, W. $(1960 a)$. The mechanism of chemical mutagenesis with special reference to triethylene melamine action. Developments in Industrial Microbiology, p. 231. New York.

SzYBALSKI, W. (1960b). Ultraviolet light sensitivity and other biological and physicochemical properties of halogenated DNA. Progress in Photobiology. Copenhagen. 
